\title{
Post Dural Puncture Headache-Review and Suggested New Treatment
}

\author{
Sharon L. Kracoff ${ }^{1}$, Vladimir Kotlovker ${ }^{2}$ \\ ${ }^{1}$ Department of Anesthesiology, Kaplan Medical Center, Rehovot, Israel \\ ${ }^{2}$ Department of Anesthesiology, Soroka University Medical Center, Beer-Sheva, Israel \\ Email: Shronkr1@clalit.org.il
}

How to cite this paper: Kracoff, S.L. and. Kotlovker, V. (2016) Post Dural Puncture Headache-Review and Suggested New Treatment. Open Journal of Anesthesiology, 6, 148-163.

http://dx.doi.org/10.4236/ojanes.2016.69024

Received: August 18, 2016

Accepted: September 27, 2016

Published: September 30, 2016

Copyright (c) 2016 by authors and Scientific Research Publishing Inc. This work is licensed under the Creative Commons Attribution International License (CC BY 4.0).

http://creativecommons.org/licenses/by/4.0/ (c) (i) Open Access

\begin{abstract}
Objectives: After reading this article, readers should be able to recognize Post Dural Puncture Headache, understand its mechanism and diagnostic criteria, evaluate the different treatment options available, and be familiar with a novel treatment option. Background: Post-dural puncture headache is the most common serious complication resulting from lumbar puncture and epidural or spinal anesthetics. The syndrome is characterized by severe headache that occurs within 48 hours following the puncture, located in the frontal and/or occipital region, worsened in the upright position and refractory to routine analgesia. The syndrome incidence was reported to be approximately $1 \%$ with typical obstetric anesthesiology practice which reflects more than 20,000 cases per 2014 in the US. Two possible mechanisms are hypothesized as responsible for this syndrome; cerebrospinal fluid leakage and pneumocephalus. Multiple methods of treatment have been applied with wide-ranging results. Design or Methods: Review article with introduction of a novel treatment option. Results: We postulate that Hyperbaric Oxygen Therapy can be used to treat postdural puncture headache. The rationale for treatment is dual: enhancement of fibroblast proliferation at the site of dural puncture to facilitate faster closure of the tear and compression of air bubbles in case of pneumocephalus according to Boyle's law. We also claim that hyperbaric oxygen therapy should be considered a prophylactic treatment, if a dural tear is suspected.
\end{abstract}

\section{Keywords}

Post Dural Puncture Headache, Lumbar Puncture, Epidural Anesthesia, Spinal Anesthesia, Headache, Hyperbaric Oxygen Therapy

\section{Introduction}

Spinal anesthesia has developed at the end of the $19^{\text {th }}$ century. Quincke and Wynter 
were the first to perform lumbar puncture (LP) in 1891 to relieve increased intracranial pressure in children with tuberculous meningitis [1]. Four years later (1895), Corning suggested local spinal anesthesia with cocaine to treat a man with habitual masturbation [2]. In 1898 Bier suffered and was the first to report Post Dural Puncture Headache (PDPH) after injecting cocaine into the subarachnoid space of seven patients including him and his assistant Hildebrandt. Bier also proposed that ongoing leakage of Cerebrospinal Fluid (CSF) was the cause of the headache. In modern day anesthesia, PDPH is reported to be the most frequent complication of spinal and epidural blocks. Despite the prevalence of the syndrome, little is known about its pathophysiology, and most accepted treatments are not evidence-based.

In the following article we attempted to gather all the information about the treatment options currently available. The purpose of the article is to introduce a new treatment option for PDPH, Hyperbaric Oxygen Therapy (HBOT). We believe that once an accidental dural puncture is suspected, HBOT should be started immediately to minimize the risk of development of PDPH. The rationale for treatment is fibroblast proliferation at the site of the puncture, the same mechanism that is applied for chronic wounds.

\section{Anatomy, Histology and Pathophysiology of Dural Puncture}

\subsection{The Meninges}

The spinal cord is surrounded by the three meninges; dura, arachnoid and pia mater. These membranes surround, support, and protect the spinal cord and spinal nerve roots, including those of the cauda equina, and contain the CSF in which these structures are suspended. The spinal dura mater; a dense vascularized collagenous connective tissue with some elastic fibers, is the outermost covering membrane of the spinal cord. Historically it was described as a longitudinal oriented structure [3] that was later confirmed by histological studies [4]. The relatively large molecular distances between the fibers allow drug and fluid movement [5]. The spinal dura is separated from the periosteum-covered bone and the ligaments that form the walls of the vertebral canal by the epidural space. The spinal dura forms the spinal dural sac, a long tubular sheath within the vertebral canal running from the foramen magnum to the coccyx. The spinal arachnoid mater is a delicate, avascular membrane composed of fibroblasts, collagen and elastic fibers that lines the spinal dural sac and its dural root sheaths. In contrast to the dura mater, the arachnoid consists of tiers of cells attached by tight junctions and occluding junctions. This phenomenon results in the impedance of drug passage into the CSF and the containment of CSF in the subarachnoid space [6]. It encloses the CSF-filled subarachnoid space containing the spinal cord, spinal nerve roots, and spinal ganglia. The spinal arachnoid is not attached to the spinal dura but is held against its inner surface by the pressure of the CSF. In a lumbar spinal puncture, the needle traverses the spinal dura and arachnoid simultaneously. Their apposition is the dura-arachnoid interface, often erroneously referred to as the "subdural space". No actual space occurs naturally at this site; it is, rather, a weak cell layer. The spinal arachnoid is separated from the pia mater on the surface of the spinal cord by the subarachnoid 
space containing CSF. The spinal pia mater, the innermost covering membrane of the spinal cord, is thin and transparent loose connective tissue that closely follows all the surface features of the spinal cord [7].

\subsection{Cerebrospinal Fluid}

The brain produces roughly $500 \mathrm{~mL}$ of cerebrospinal fluid per day $(0.35 \mathrm{~mL} / \mathrm{min})$. This fluid is constantly reabsorbed, so that only $100-160 \mathrm{~mL}$ is present at any one time. Ependymal cells of the choroid plexus produce more than two thirds of CSF.

\subsection{Dural Puncture and Loss of CSF-The "Leak Theory"}

Neurosurgical experience of dural perforation is that even minor perforations need to be closed, either directly or through the application of synthetic or biological dural graft material, otherwise continuous CSF leak, adhesions or infection may occur [8]. Upon perforation of the dura mater CSF leakage occurs. Excessive CSF loss can lead to intracranial hypotension (ICH) which is one possible mechanism for the development of $\mathrm{PDPH}$. A possible explanation for the headache is via the Monro-Kellie doctrine [9]; the decrease in CSF fluid leads to a compensatory increase in blood volume. The headache is therefore caused by venodilation. Advances in neuroimaging have improved the ability to correlate CSF loss to the diagnosis of ICH and PDPH. Spinal magnetic resonance imaging (MRI) has demonstrated extra-arachnoid fluid collections, spinal meningeal enhancement and dilation of the epidural venous plexus [10] in the presence of ICH and PDPH. MRI also assists in locating the site of the CSF leak, even if the leakage is not active [11]. Radioisotope cisternography is another modality that confirmed the presence of CSF leakage. This test however, yields a positive result only if an active leak is present. Radionucleide myelography, computed tomography myelography, manometric studies, epiduroscopy and direct visualization at laminectomy have also proved the presence of a CSF leak when the cause of PDPH was sought [8].

\subsection{Dural Puncture and Pneumocephalus-The "Air Theory"}

Pneumocephalus (PC) is defined as a pathological collection of gas within the cranial cavity. Most cases of PC following epidural techniques have been associated with the Loss of Resistance Technique (LOR). The LOR technique is widely used either with air or saline to identify the epidural space. PC is a rare complication of inadvertent dural puncture and injection of air into the subarachnoid or subdural space [12] [13]. It is assumed that the symptomatic headache arise from irritation of the spinal roots by air migrating cranially in the sitting patient [14]. Diagnosis can be done by imaging modalities such as CT, MRI or an XR of the skull showing air trapped in the spine and brain [15].

\section{Clinical Features}

According to the International Headache Society [16] there are four criteria for PDPH which include a headache that develops within 5 days after dural puncture, worsens within 15 minutes after sitting or standing and improves within 15 minutes after lying 
down, accompanied by at least one of the following: neck stiffness, nausea, photophobia, tinnitus and hypoacusia, and resolves either spontaneously within one week or within 48 hours after effective treatment of the spinal fluid leak. Typically, the patient complains of severe headache, characteristically located in the frontal and or the occipital region. The pain is worsened with the upright position and improves with lying down. Any movement that increases intracranial pressure (such as coughing, sneezing, straining, or ocular compression) may exacerbate symptoms [17]. Signs that may be found on physical examination of the patient include the Gutsche sign: the application of firm manual pressure around the abdomen of the seated patient produces transient relief. Nuchal rigidity may also be seen. Other patients may have a cranial nerve palsy inducing diplopia [17].

\section{Incidence}

The incidence of PDPH in 1898 was $66 \%$ as reported by Wulf [18]. With the introduction of $22 \mathrm{G}$ and $24 \mathrm{G}$ needles in 1956, Dripps and Vandam reported decreased incidence after examining 10,098 cases of spinal anesthesia [19]. In 1992 Kuntz et al. [20] reported an overall incidence of PDPH from $0.1 \%$ - 36\%, the highest incidence of $36 \%$ was found after ambulatory diagnostic lumbar puncture using a 20 or 22 guage standard Quincke spinal needles. A year later Reynolds [21] reported an incidence of $0.16 \%$ - $1.3 \%$. Obstetrical patients tend to have a greater incidence of post-dural puncture headaches, which is most likely caused by the larger size of the needle used for epidural anesthesia. Most of these are the result of epidurals that are accidentally converted to spinal cases [17]. In 2014 the incidence of PDPH was reported to be approximately $1 \%$ with typical obstetric anesthesiology practice which reflects more than 20,000 cases per 2014 in the US [5].

\subsection{Factors Influencing Incidence}

Common risk factors of PDPH include female gender, particularly females during pregnancy, age groups of 20 - 40, a prior history of PDPH or headache, and a lower body mass index [22]. Younger women were showed to have a greater risk for PDPH due to their fiber elasticity that maintains a patent dural defect compared to decreased elasticity in an older age [23]. Cigarette smokers were found to have a lower incidence of PDPH, possibly due to the clot-promoting properties of smoking that facilitate the occlusion of the dural puncture [24]. The experience of the physician performing the procedure was showed to be irrelevant in a series of 501 patients with PDPH [20], however under current understanding it stands to reason that the higher the number of attempts at dural puncture, the higher the likelihood of dural puncture damage, CSF leak and PDPH [25]. There is no available study that examined this relationship to date.

\section{Risk Factors and Prevention}

Literature clearly indicates that there are several risk factors that may increase the risk to PDPH and ways to avoid them. 


\subsection{Needle Size}

The smaller the needle size the smaller the dural defect and therefore the smaller the incidence of PDPH. Dieterich et al. [26] found that PDPH incidence was much lower with the use of 24 - 27 gauge needles (5\% - 12\%) compared with 20 - 22 gauge needles $(20 \%-40 \%)$.

\subsection{Needle Design}

There have been many studies comparing one or more types of pencil-point spinal needles with Quincke point needles that have consistently shown lower PDPH with the pencil point type. Cutting needles (Quincke) are associated with higher incidence of PDPH compared with pencil point/atraumatic/non-cutting needles (Sprotte, GM, Whitacre). Hart and Whitacre reported in 1951 lower headache rates with a new pencil point needle [27]. Sprotte [28] described in his paper in 1987, 34,950 procedures with new $24 \mathrm{G}$ and $22 \mathrm{G}$ Sprotte needles with headache rate of $0.02 \%$. Strup et al. [29] reported in 2001 his results of a prospective double-blinded trial involving 230 patients who were randomly assigned to diagnostic Lumbar puncture with a 22-gauge atraumatic Sprotte needle or a 22-gauge cutting Quincke needle. Use of the atraumatic needle was associated with lower frequency of PDPH. Cutting needles were thought to be more traumatic because they cut across the longitudinal fibers of the dura and prevent the retracting dural fibers from sealing the puncture site when removed [25], however, microscopic dissection of cadaveric dura mater revealed that dura fibers run concentrically around the medulla spinalis [30]. On electron microscopy it has been shown that pencil point needles are actually more traumatic to the dura compared with the cutting needles. It is therefore postulated that the trauma caused by the pencil point needle produces a greater local inflammatory reaction that helps seal the dural puncture leak more effectively [31].

The smaller the needle size the smaller the dural defect and therefore the smaller the incidence of PDPH. Dieterich et al. [26] found that PDPH incidence was much lower with the use of $24-27$ gauge needles (5\% - 12\%) compared with 20 - 22 gauge needles $(20 \%-40 \%)$.

\subsection{Needle Orientation}

A longitudinal bevel orientation is more favorable in reducing the risk of PDPH when compared with a perpendicular orientation as showed in several laboratory [32] [33] and clinical [34] [35] studies.

\subsection{Reinsertion of the Stylet}

A randomized prospective trail of 600 patients undergoing diagnostic lumbar puncture found that reinsertion of the stylet prior to removing the needle versus no insertion resulted is associated with a lower incidence of PDPH [36].

Other factors such as patient positioning after the procedure [37] and bed rest [38]-[41] were shown to have no effect on the development of PDPH. 


\subsection{Prevention}

A large meta-analysis was conducted in 2012 by Bardbury et al. [42]. They searched for randomized clinical trials (RCTs) of parturients having labor epidurals, in which the studied intervention could plausibly affect accidental dural puncture (ADP) or PDPH, and the incidence of at least one of these was recorded. Forty RCTs ( $n=11,536$ epidural insertions) were included, studying combined spinal-epidurals (CSEs), loss of resistance medium, prophylactic epidural blood patches, needle bevel orientation, ultrasound-guided insertion, epidural morphine, Special Sprotte needles, acoustic-guided insertion, administration of cosyntropin, and continuous spinal analgesia. Five methods were shown to reduce PDPH: prophylactic blood patch, lateral orientation of the needle bevel during insertion, use of non-cutting point epidural needle, epidural morphine, and administration of cosynotropin.

\section{Treatment}

After confirming the diagnosis of PDPH, initial treatment for the first 24 - 48 hours should remain conservative and include bed rest, oral analgesics that do not degrade platelet function such as opioids and hydration to maintain euvolemia. There is no evidence that vigorous hydration has any therapeutic benefit, or that it encourages an increased production of CSF, however no patient with PDPH should be allowed to become dehydrated [43]. If the diagnosis of PC has been made, there should be additional administration of $40 \%-100 \%$ oxygen in the supine position [44]. Epidural infusions or blood patch has no effect on PC [45] [46]. In the Table 1 summarized some of the possible drug treatments. For patients with a prolonged manifestation of PDPH an invasive treatment is suggested.

\subsection{Pharmacotherapy}

Table 1. Pharmacotherapy.

\begin{tabular}{|c|c|c|c|c|}
\hline Opioids & $\begin{array}{l}\text { Interact with opioid receptors in } \\
\text { the central nervous system. }\end{array}$ & Oral/IV & Pain relief & Nausea and Vomiting \\
\hline Caffeine & $\begin{array}{l}\text { Central nervous system } \\
\text { stimulant, reversibly blocks } \\
\text { cerebral adenosine receptors } \\
\text { which lead to vasoconstriction } \\
\text { of dilated cerebral blood vessels. }\end{array}$ & $\begin{array}{l}\text { Oral/IV ( } 300 \text { - } 500 \mathrm{mg} \text { ) once or } \\
\text { twice daily. Single oral dose for } \\
\text { mild PDPH was proved to be safe } \\
\text { [47]. Caffeine Sodium Benzoate as } \\
\text { an IV Bolus/Infusion was proved } \\
\text { to be } 75 \%-80 \% \text { effective [ } 48 \text { ] }\end{array}$ & Temporary pain relief & $\begin{array}{l}\text { Return of headache } 48 \mathrm{hr} \text { after } \\
\text { the IV administered dose }\end{array}$ \\
\hline Sumatriptan & $\begin{array}{l}\text { Serotonin type 1-d receptor } \\
\text { agonist, vasoconstriction of } \\
\text { intracranial blood vessels. }\end{array}$ & Subcutaneous & $\begin{array}{l}\text { Variable results: a few case } \\
\text { reports have reported } \\
\text { improvement of symptoms } \\
\text { [49] while clinical trials } \\
\text { have proved inefficacy [50] } \\
\text { [51] }\end{array}$ & $\begin{array}{l}\text { Pain at the site of injection } \\
\text { Chest tightness } \\
\text { Caution in patients with Ischemic } \\
\text { Heart Disease } \\
\text { Expensive drug }\end{array}$ \\
\hline
\end{tabular}




\begin{tabular}{|c|c|c|c|c|}
\hline Gabapentin & $\begin{array}{l}\text { A structural analogue of } \\
\text { gamma-amino-butyric-acid } \\
\text { (GABA). Likely increases the } \\
\text { concentration of GABA in the } \\
\text { brain. }\end{array}$ & $\begin{array}{l}\text { Oral }(300-400 \mathrm{mg}) \text { every } 8 \mathrm{hr} \text { for } \\
4 \text { days }\end{array}$ & $\begin{array}{l}\text { Decreases VAS score for } 5 \\
\text { days [52] }\end{array}$ & \\
\hline Hydrocortisone & $\begin{array}{l}\text { Corticosteroid hormone } \\
\text { receptor agonist. }\end{array}$ & $\begin{array}{l}\text { IV }(200 \mathrm{mg} \text { ) and then } 100 \mathrm{mg} \\
\text { three times a day (oral) for } 48 \\
\text { hours }\end{array}$ & $\begin{array}{l}\text { Decreased VAS score by } \\
50 \% 6 \mathrm{hrs} \text { later and } 75 \% 24 \\
\text { h after treatment }[53][54]\end{array}$ & $\begin{array}{l}\text { Sodium retention-related weight } \\
\text { gain, fluid accumulation, } \\
\text { hyperglycemia, hypokalemia, } \\
\text { gastrointestinal ulceration, mood } \\
\text { changes }\end{array}$ \\
\hline Cosyntropin & $\begin{array}{l}\text { Synthetic adrenocorticotropic } \\
\text { hormone (ACTH). Stimulates } \\
\text { the adrenal gland to increase } \\
\text { CSF production and } \\
\beta \text {-endorphin output. Fluid and } \\
\text { electrolyte retention. }\end{array}$ & $\begin{array}{l}60 \text { units IM } \\
1.5 \text { units/kg IV }\end{array}$ & $\begin{array}{l}\text { Pain relief at days } 3 \text { - } 7 \text { [55] } \\
\text { Multiple studies have } \\
\text { showed efficacy [51] [56] } \\
\text { [57] }\end{array}$ & $\begin{array}{l}\text { Caution in patients with diabetes } \\
\text { and hypertension due to } \\
\text { increased blood glucose levels } \\
\text { and fluid and electrolytes } \\
\text { retention [55] [58] }\end{array}$ \\
\hline
\end{tabular}

\subsection{Invasive Treatment}

Patients who do not respond to conservative treatment within 48 hours are subjected to invasive treatments.

\subsubsection{Epidural Blood Patch}

Epidural blood patch (EBP) has become the "Gold Standard" in the treatment of PDPH [43]. It is a relatively simple procedure; sterile autologous blood is injected epidurally at or near the site of the dural puncture. Prophylactic antibiotics are rarely used. It is believed to works via a dual mechanism: volume replacement and sealing of the CSF leak by local blood clot formation. Gormley [59] was the first to conclude that blood can serve as a sealing material. In his study he injected $2-3 \mathrm{ml}$ of blood to 7 patients (including himself) suffering from PDPH at the site of the puncture. His idea was later supported by DiGiovanni and Dunbar [60]. Literature suggests injecting volumes of 5 $30 \mathrm{~mL}$ [61]-[63] but practice suggests that the optimal volume is the one at which significant pressure occurs in the back, buttock or lower limbs. Abouleish et al. [64] studied 524 cases and reported $>95 \%$ relief of PDPH following EBP, when using volumes of blood $>15 \mathrm{~mL}$. Crawford [65] injected $20 \mathrm{ml}$ of blood and showed success rate of $97 \%$. Other studies published later on offered lower success rates varying between $61 \%$ - 75\% [66] [67]. A systematic review published in 2010 showed that EBP reduce the duration and intensity of PDPH compared with conservative treatment [63], however another report showed that relief of PDPH after the first epidural patch is roughly 50\% and that up to $40 \%$ of patients will require a second patch [68]. Two early randomized controlled trials showed efficacy with the use of EBP [69] [70]. In another RCT conducted later, a prophylactic EBP was found to shorten hospital stay but did not prevent PDPH [71]. A Cochrane meta-analysis from 2010 supported the benefit of a prophylactic blood patch in preventing PDPH [63]. However, though it seems a highly effective treatment with minor complications, up to $30 \%$ of patients will experience recurrence of symptoms and require a second EBP [62] [72]. If two blood patches have been com- 
pleted and the patient's headache still persists, then imaging is probably warranted in most situations to confirm that the proper diagnosis has been made, although if each EBP is successful, there is a strong possibility that PDPH is the diagnosis and the EBP is simply failing to provide permanent relief [5]. Even though considered the "Gold Standard" treatment EBP is an invasive treatment option that does not come without its complications; the most common complication is backache which is probably caused due to local nerve root irritation and can last up to 5 days [66]. Other major complications caused by an accidental injection of the blood intrathecally, instead of epidurally, are rare and include; blood-borne infections such as arachnoiditis or meningitis and various neurological deficits such as cauda equine syndrome or permanent nerve damage. Other complications reported in the literature include; facial nerve paralysis, spinal subdural hematoma (following large volume injections), dizziness, tinnitus, vertigo, and ataxia. Intraventricular blood and pneumocephalus after an EBP were reported by Chen and Hillen [73], both resolved spontaneously without treatment.

\subsubsection{Epidural Saline or Colloid Solution}

It is quit agreeable that an autologous EBP for the treatment of PDPH can be worrisome. Therefore it was thought that an injection of a solution such as saline would in theory, produce the same effect. Colloid solutions (dextran 40\%, hydroxyethylstarch, modified fluid gelatin) and saline injections at the site of the prior lumbar puncture are believed to decrease CSF leakage by restoring the subarachnoid pressure; however, the effect is transient due to their quick dispersion. A few case studies showed relief of the headache in most patients, but with high rate (50\%) of recurrence [74] [75]. A large comparative study of saline with epidural blood patches has not demonstrated the long-term efficacy of epidural saline placement [76]. It seems however, that colloid solutions are favorable compared to epidural saline; their high molecular weight and viscosity produce a longer effect of epidural pressure and seal of the defect. There is not enough evidence to support this argument.

\subsubsection{Epidural Morphine}

Eldor et al. [77] were the first to show that injection of 3.5 - $4.5 \mathrm{mg}$ of morphine via an epidural catheter caused total relief of the pain in 6 patients. A study published later on supported this idea; administration of $3 \mathrm{mg}$ morphine epidurally significantly reduced PDPH and the need for EBP [78].

\subsubsection{Fibrin Glue}

Another alternative agent to blood that has been proposed to repair dural perforation is fibrin glue [79]. Fibrin glue consists of two biological components including thrombin solution and fibrinogen. The concept of their interaction is based on the last step of the coagulation cascade; thrombin converts fibrinogen into fibrin monomers giving rise to a three dimensional gel within seconds [80].

Fibrin glue is most frequently used in neurosurgery to repair cranial dural perforations. There is not enough evidence to support the use of fibrin glue for PDPH. Crul et al. [81] reported in 1999 a case of a 29-year-old patient who suffered from persistent 
PDPH with the uneventful treatment of an epidural blood patch. She was successfully treated with local injection of fibrin glue. There is however, an increased risk for infections, immune reactions and anaphylaxis because fibrinogen is a biological material derived from pooled human plasma.

\subsubsection{Intrathecal Catheter}

This involves placement of a catheter through the dural perforation. The mechanism of action is believed to be a local inflammatory reaction created by the catheter that promotes dural tear healing and reduce the CSF leak [61]. A meta-analysis by Heesen et al. [82] found that insertion of an intrathecal catheter significantly reduced the risk for an EPB, however the incidence of PDPH wasn't reduced significantly.

\subsubsection{Surgery}

Cases that are unresponsive to the above suggested therapy are subjected to surgery. This is clearly a last resort treatment [8].

\section{Suggested New Treatment}

We came up with a new treatment for PDPH, weather it is due to a CSF leak or due to the less frequent cause: PC. Hyperbaric Oxygen Therapy (HBOT) is defined by the Undersea and Hyperbaric Medical Society (UHMS) as an intervention in which an individual breathes near 100\% oxygen intermittently while inside a hyperbaric chamber that is pressurized to pressure greater than sea level (1 Atmosphere Absolute or ATA). Indications for hyperbaric treatment as published by the UHMS include: air or gas embolism, carbon monoxide poisoning, gas gangrene, acute traumatic ischemia, decompression sickness, arterial insufficiencies, severe anemia, intracranial abscess, necrotizing soft tissue infections, refractory osteomyelitis, delayed radiation injury, compromised grafts and flaps, acute thermal bone injury and idiopathic sudden sensorineural hearing loss. The mechanism of action on HBOT is dual and based on elevation of both the partial pressure of inspired $\mathrm{O}_{2}$ and the hydrostatic pressure. Elevation of the hydrostatic pressure compresses the gas-filled spaces in the body (Boyle's Law) and is relevant when gas-babbles are present in the body (PC). On the other hand, elevation of the $\mathrm{O}_{2}$ partial pressure increases the tissue production of Reactive Oxygen Species (ROS) and Reactive Nitrogen Species (RNS) therefore promoting modulation of intracellular transduction cascades, leading to synthesis of growth factors and promoting wound healing [83]. HBOT has been mentioned before as a therapeutic option for PC. Shih et al. [84] presented a case of a 36-year-old woman with cardiopulmonary arrest and deep coma caused by epidural anesthesia-induced PC. She was treated successfully with one session of HBOT of 120 minutes at 2.8 atm absolute pressure with $100 \%$ oxygen concentration. Plava et al. [85] conducted a small study to assess the benefits of HBOT for the treatment of symptomatic PC. Their study population was mostly patients who suffered traumatic head injuries, and presented with symptomatic PC. Even though their study had some limitations, they managed to show that HBOT in selective cases may lead to clinical and radiological improvement and can shorten hospital stay. 
We believe that HBOT can be offered as a dual-mechanism-treatment for PDPH; weather the cause is CSF leak or the rarer presentation of PC. HBOT serves not only as a successful treatment for PC, but also as an adjunctive therapy for wound healing. The rationale for treatment of chronic wounds with HBOT is improved angiogenesis through fibroblast proliferation and collagen synthesis. Work published in 1959 tried to explain the mechanism of dural response to perforation. Keener [86] maintained that dural repair can be facilitated by fibroblastic proliferation from the surrounding tissue and the local formation of a blood clot. We postulate that HBOT may improve fibroblast proliferation at the site of the dural tear and will therefore facilitate its closure. Furthermore, we think that HBOT should be considered prophylactically once dural puncture is suspected, since PDPH will most probably develop later on.

\section{References}

[1] Qunicke, H.I. (1909) Lumbar Puncture. Diseases of the Nervous System. Church, A., Ed., Appleton, New York, 223.

[2] Gorelick, P.B. and Zych, D. (1987) James Leonard Corning and the Early History of Spinal Puncture. Neurology, 37, 672-674. http://dx.doi.org/10.1212/WNL.37.4.672

[3] Green, H.M. (1926) Lumbar Puncture and the Prevention of Post Puncture Headache. JAMA, 86, 391-392. http://dx.doi.org/10.1001/jama.1926.02670320005002

[4] Patin, D.J., Eckstein, E.C., Harum, K. and Pallares, V.S. (1993) Anatomic and Biomechanical Properties of Human Lumbar Dura Mater. Anesthesia \& Analgesia, 76, 533-540. http://dx.doi.org/10.1213/00000539-199303000-00014

[5] Sachs, A. and Smiley, R. (2014) Post Dural Puncture Headache: The Worst Common Complication in Obstetric Anesthesia. Seminars in Perinatology, 38, 386-394. http://dx.doi.org/10.1053/j.semperi.2014.07.007

[6] Bernards, C.M. (2005) Sophistry in Medicine: Lessons from the Epidural Space. Regional Anesthesia and Pain Medicine, 30, 56-66. http://dx.doi.org/10.1097/00115550-200501000-00007

[7] Moore, K.L., Agur, A.M.R. and Dalley, A.F. (2013) Clinically Oriented Anatomy. 7th Edition, LWW, Philadelphia, Chapter 4 "Back", 498-507.

[8] Turnbull, D.K. and Shepherd, D.B. (2003) Post-Dural Puncture Headache: Pathogenesis, Prevention and Treatment. British Journal of Anesthesia, 91, 718-729. http://dx.doi.org/10.1093/bja/aeg231

[9] Grant, R., Condon, B., Hart, I. and Teasdale, G.M. (1991) Changes in Intracranial CSF Volume after Lumbar Puncture and Their Relationship to Post-LP Headache. Journal of Neurology, Neurosurgery \& Psychiatry, 54, 440-442. http://dx.doi.org/10.1136/jnnp.54.5.440

[10] Paldino, M., Mogilner, A.Y. and Tenner, M.S. (2003) Intracranial Hypotension Syndrome: A Comprehensive Review. Neurosurgical Focus, 15, 1-8.

http://dx.doi.org/10.3171/foc.2003.15.6.8

[11] Matsumara, A., Anno, I., Nose, T., Fujimoto, A., Shibata, Y. and Okazaki, M. (2001) Intra- 
cranial Hypotension. Journal of Neurosurgery, 95, 914-916.

[12] Wang, J.C., Tsai, S.H. and Liao, W.I. (2014) Pneumocephalus after Epidural Anesthesia in an Adult Who Has Undergone Lumbar Laminectomy. Journal of Neurosurgical Anesthesiology, 26, 261-263. http://dx.doi.org/10.1097/ANA.0000000000000004

[13] Nafiu, O.O. and Urquhart, J.C. (2006) Pneumocephalus with Headache Complicating Labor Epidural Analgesia: Should We Still Be Using Air? International Journal of Obstetric Anesthesia, 15, 237-239. http://dx.doi.org/10.1016/j.ijoa.2005.10.011

[14] Dittmann, M., Schaefer, H.G., Renkl, F. and Greve, I. (1994) Spinal Anesthesia with 29 Gauge Quincke Point Needles and Post-Dural Puncture Headache in 2378 Patients. Acta Anaesthesiologica Scandinavica, 38, 691-693. http://dx.doi.org/10.1111/j.1399-6576.1994.tb03978.x

[15] Moayeri, N.N., Henson, J.W., Schaefer, P.W. and Zervas, N.T. (1998) Spinal Dural Enhancement on Magnetic Resonance Imaging Associated with Spontaneous Intracranial Hypotension. Report of Three Cases and Review of the Literature. Journal of Neurosurgery, 88, 912-918. http://dx.doi.org/10.3171/jns.1998.88.5.0912

[16] International Headache Society. http://ihs-classification.org/en/02 klassifikation/03 teil2/07.02.01 nonvascular.html

[17] Younggren, B. and Merchant, E. (2007) Focus on: Post Dural Puncture Headache. American College of Emergency Physicians.

http://www.acep.org/Clinical---Practice-Management/Focus-On--Post-Dural-Puncture-He adache/

[18] Wulf, H.F. (1998) The Centennial of Spinal Anesthesia. Anesthesiology, 89, 500-506. http://dx.doi.org/10.1097/00000542-199808000-00028

[19] Vandam, L.D. and Dripps, R.D. (1956) Long Term Follow up of Patients Who Received 10,098 Spinal Anesthetics. JAMA, 161, 586-591.

http://dx.doi.org/10.1001/jama.1956.02970070018005

[20] Kuntz, K.M., Kohmen, E., Stevens, J.C., Miller, P., Offord, K.P. and Ho, M.M. (1992) Post Lumbar Puncture Headache: Experience in 501 Consecutive Procedures. Neurology, 42, 1884-1887. http://dx.doi.org/10.1212/WNL.42.10.1884

[21] Reynolds, F. (1993) Dural Puncture and Headache. BMJ, 306, 874-876. http://dx.doi.org/10.1136/bmj.306.6882.874

[22] Liu, S., Carpenter, R.L. and Neal, J.M. (2001) Epidural Anesthesia and Analgesia: Their Role in Postoperative Outcome. Anesthesiology, 82, 582-587.

[23] Evans, R.W. (1998) Complications of Lumbar Puncture. Neurologic Clinics, 16, 83-105. http://dx.doi.org/10.1016/S0733-8619(05)70368-6

[24] Dodge, H.S., Ekhator, N.N., Jefferson-Wilson, L., Fischer, M., Jansen, L., Horn, P.S., Hurford, W.E. and Geracioti, T.D. (2013) Cigarette Smokers Have Reduced Risk for Post Dural Puncture Headache. Pain Physician, 16, E25-E30.

[25] Omole, O.B. and Ogunbanjo, G.A. (2015) Post Puncture Headache: Evidence-Based Review 
for Primary Care. South African Family Practice, 57, 241-346.

http://dx.doi.org/10.1080/20786190.2015.1014154

[26] Dieterich, M. and Perkin, G.D. (1996) Post Lumbar Puncture Headache Syndrome. Neurological Disorders. Course and Treatment, 59-63.

[27] Hart, J.R. and Whitacre, R.J. (1951) Pencil Point Needle in Prevention of Post Spinal Headache. JAMA, 147, 657-658. http://dx.doi.org/10.1001/jama.1951.73670240021006k

[28] Sprotte, G., Schedel, R., Pajunk, H. and Pajunk, H. (1987) An Atraumatic Universal Needle for Single-Shot Regional Anesthesia: Clinical Results and a 6 Year Trial in over 30,000 Regional Anesthesias. Regional Anesthesia, 10, 104-108.

[29] Strupp, M., Schueler, O., Straube, A., Von Stuckrad-Barre, S. and Brandt, T. (2001) Atraumatic Sprotte Needle Reduces the Incidence of Post Lumbar Puncture Headaches. Neurology, 57, 2310-2312. http://dx.doi.org/10.1212/WNL.57.12.2310

[30] Reina, M.A., Dittmann, M., Garcia, A.L. and Van Zundert, A. (1997) New Perspectives in the Microscopic Structure of Human Dura Mater in the Dorsolumbar Region. Regional Anesthesia, 22, 161-166. http://dx.doi.org/10.1016/S1098-7339(06)80036-2

[31] Reina, M.A., de Leon-Casasola, O.A., Lopez, A., De Andres, J., Martin, S. and Mora, M. (2000) An in Vitro Study of Dural Lesions Produced by 25-Gauge Quincke and Whitacre Needles Evaluated by Scanning Electron Microscopy. Regional Anesthesia and Pain Medicine, 25, 393-402. http://dx.doi.org/10.1097/00115550-200007000-00013

[32] Dittmann, M., Schaefer, H.G., Ulrich, J. and Bond-Taylor, W. (1988) Anatomical Re-Evaluation of Lumbar Dura Mater with Regard to Post Spinal Headache. Effect of Dural Puncture. Anesthesia, 43, 635-637. http://dx.doi.org/10.1111/j.1365-2044.1988.tb04145.x

[33] Ready, L.B., Cuplin, S., Hschke, R.H. and Nessly, M. (1989) Spinal Needle Determinants of Rate of Transdural Fluid Leak. Anesthesia \& Analgesia, 69, 457-460. http://dx.doi.org/10.1213/00000539-198910000-00006

[34] Lybecker, H., Moller, J.T., May, O. and Nielsen, H.K. (1990) Incidence and Prediction of Post Dural Puncture Headache. A Prospective Study of 1021 Spinal Anesthesias. Anesthesia \& Analgesia, 70, 389-394. http://dx.doi.org/10.1213/00000539-199004000-00008

[35] Norris, M.C., Leighton, B.L. and Desimone, C.A. (1989) Needle Bevel Direction and Headache after Inadvertent Dural Puncture. Anesthesiology, 70, 729-731.

http://dx.doi.org/10.1097/00000542-198905000-00002

[36] Strupp, M., Brandt, T. and Muller, A. (1998) Incidence of Post Lumbar Puncture Syndrome Reduced by Reinserting the Stylet: A Randomized Prospective Study of 600 Patients. Journal of Neurology, 245, 589-592. http://dx.doi.org/10.1007/s004150050250

[37] Raskin, N.H. (1990) Lumbar Puncture Headache: A Review. Headache, 30, 197-200. http://dx.doi.org/10.1111/j.1526-4610.1990.hed3004197.x

[38] Vilming, S.T., Schrader, H. and Monstad, I. (1988) Post-Lumbar-Puncture Headache: The Significance of Body Posture. A Controlled Study of 300 Patients. Cephalalgia, 8, 75-78. http://dx.doi.org/10.1046/j.1468-2982.1988.0802075.x

[39] Thoennissen, J., Herkner, H., Lang, W., Domanovits, H., Laggner, A.N. and Müllner, M. 
(2001) Does Bed Rest after Cervical or Lumbar Puncture Prevent Headache? A Systematic Review and Meta-Analysis. CMAJ, 165, 1311-1316.

[40] Ebinger, F., Kosel, C., Pietz, J. and Rating, D. (2004) Strict Bed Rest Following Lumbar Puncture in Children and Adolescents Is of No Benefit. Neurology, 62, 1003-1005. http://dx.doi.org/10.1212/01.WNL.0000115387.67958.0F

[41] Arevalo-Rodriguez, I., Ciapponi, A., Munoz, L., Roquéi Figuls, M. and Bonfill Cosp, X. (2013) Posture and Fluids for Preventing Post-Dural Puncture Headache. Cochrane Database of Systematic Reviews, 7, Article ID: CD009199. http://dx.doi.org/10.1002/14651858.cd009199.pub2

[42] Bradbury, C.L., Singh, S.I., Badder, S.R., Wakely, L.J. and Jones, P.M. (2013) Prevention of Post-Dural Puncture Headache in Parturients: A Systematic Review and Meta-Analysis. Acta Anaesthesiologica Scandinavica, 57, 417-430. http://dx.doi.org/10.1111/aas.12047

[43] Ghaleb, A. (2010) Post Dural Puncture Headache. Anesthesiology Research and Practice, 2010, Article ID: 102967. http://dx.doi.org/10.1155/2010/102967

[44] Kim, Y.J., Balik, H.J. and KIM, J.H. (2009) Pneumocephalus Developed during Epidural Anesthesia for Combined Spinal-Epidural Anesthesia. Korean Journal of Pain, 22, 163-166. http://dx.doi.org/10.3344/kjp.2009.22.2.163

[45] Aida, S., Taga, K. and Yamakura, T. (1998) Headache after Attempted Epidural Block: The Role of Intrathecal Air. Anesthesiology, 88, 76-81.

[46] Nafiu, O.O. and Urquhart, J.C. (2006) Pneumocephalus with Headache Complicating Labor Epidural Analgesia: Should We Still Be Using Air? International Journal of Obstetric Anesthesia, 15, 237-239. http://dx.doi.org/10.1016/j.ijoa.2005.10.011

[47] Thornberry, E.A. and Thomas, T.A. (1988) Posture and Post-Spinal Headache. A Controlled Trial in 80 Obstetric Patients. British Journal of Anesthesia, 60, 195-1957. http://dx.doi.org/10.1093/bja/60.2.195

[48] Camann, W.R., Murray, R.S., Mushlin, P.S. and Lambert, D.H. (1990) Effect of Oral Caffeine on Post Dural Puncture Headache. A Double Blind, Placebo Controlled Trial. Anesthesia and Analgesia, 70, 181-184. http://dx.doi.org/10.1213/00000539-199002000-00009

[49] Hudgson, C. and Roitberg-Henry, A. (1997) The Use of Sumatriptan in the Treatment of Post Dural Puncture Headache. Anaesthesia, 52, 808-809.

[50] Connelly, N.R., Parker, R.K., Rahimi, A. and Gibson, C.S. (2000) Sumatriptan in Patients with Post Dural Puncture Headache. Headache, 40, 316-319.

http://dx.doi.org/10.1046/j.1526-4610.2000.00047.x

[51] Basurto Ona, X., Martinez, G.L., Sola, L. and Bonfill, C.X. (2011) Drug Therapy for Treating Post Dural Puncture Headache. Cochrane Database of Systematic Reviews, 10, Article ID: CD007887. http://dx.doi.org/10.1002/14651858.CD007887.pub2

[52] Erol, D.D. (2011) The Analgesic and Antiemetic Efficacy of Gabapentin or Ergotamine/ Caffeine for the Treatment of Post Dural Puncture Headache. Advances in Medical Sciences, 56, 25-29. http://dx.doi.org/10.2478/v10039-011-0009-Z

[53] Alam, M.R., Rahman, M. and Ershad, R. (2012) Role of Very Short Term Intravenous Hy- 
drocortisone in Reducing Post Dural Puncture Headache. Journal of Anaesthesiology Clinical Pharmacology, 28, 190-193. http://dx.doi.org/10.4103/0970-9185.94840

[54] Noyan Ashraf, M.A., Sadeghi, A., Azarbakht, Z., Salehi, S. and Hamediseresht, E. (2007) Evaluation of Intravenous Hydrocortisone in Reducing Headache after Spinal Anesthesia: A Double Blind Controlled Clinical Study. Middle East Journal of Anesthesiology, 19, 415422.

[55] Melville, N.A. (2015) Cosynotropin Shows Efficacy for Post Dural Puncture Headache.

[56] Hakim, S.M. (2010) Cosyntropin for Prophylaxis against Post Dural Puncture Headache after Accidental Dural Puncture. Anesthesiology, 113, 413-420.

http://dx.doi.org/10.1097/ALN.0b013e3181dfd424

[57] Gupta, S. and Agrawal, A. (1997) Post Dural Puncture Headache and ACTH. Journal of Clinical Anesthesia, 9, 258. http://dx.doi.org/10.1016/S0952-8180(97)00042-1

[58] Carter, B.L. and Pasupuleti, R. (2000) Use of Intravenous Cosynotropin in the Treatment of Post Dural Puncture Headache. Anesthesiology, 92, 272-274. http://dx.doi.org/10.1097/00000542-200001000-00043

[59] Gormley, J.B. (1960) Treatment of Post Spinal Headache. Anesthesiology, 21, 565-566.

[60] Di Giovanni, A.J. and Dunbar, B.S. (1970) Epidural Injection of Autologous Blood for PostLumbar Puncture Headache. Anesthesia and Analgesia, 49, 268-271.

[61] Apfel, C.C., Saxena, A., Cakmakkaya, O., Gaiser, R., George, E. and Radke, O. (2010) Prevention of Post Dural Puncture Headache after Accidental Dural Puncture: A Quantitative Systemic Review. British Journal of Anaesthesia, 105, 225-263. http://dx.doi.org/10.1093/bja/aeq191

[62] Paech, M.J., Doherty, D.A., Christmas, T., Wong, C.A. and Epidural Blood Patch Trail Group (2011) The Volume of Blood for Epidural Blood Patch in Obstetrics: A Randomized, Blinded Clinical Trial. Anesthesia \& Analgesia, 113, 126-133. http://dx.doi.org/10.1213/ANE.0b013e318218204d

[63] Boonmark, P. and Boonmark, S. (2010) Epidural Blood Patching for Preventing and Treating Post Dural Puncture Headache. Cochrane Database of Systematic Reviews, 20, Article ID: CD001791. http://dx.doi.org/10.1002/14651858.CD001791.pub2

[64] Abouleish, E., De La Vega, S., Blendinger, I. and Tio, T.O. (1975) Long Term Follow-Up of Epidural Blood Patch. Anesthesia and Analgesia, 54, 459-463.

http://dx.doi.org/10.1213/00000539-197554040-00012

[65] Craford, J.S. (1980) Experiences with Epidural Blood Patch. Anesthesia, 35, 513-515. http://dx.doi.org/10.1111/j.1365-2044.1980.tb03834.x

[66] Taivainen, T., Pitkanen, M., Tuominen, M. and Rosenberg, P.H. (1993) Efficacy of Epidural Blood Patch for Post Dural Puncture Headache. Acta Anaesthesiologica Scandinavica, 37, 702-705. http://dx.doi.org/10.1111/j.1399-6576.1993.tb03793.x

[67] Safa-Tisseront, V., Thormann, F., Malassine, P., Henry, M., Riou, B., Coriat, P. and Seebacher, J. (2001) Effectiveness of Epidural Blood Patch in the Management of Post Dural Puncture Headache. Anesthesiology, 95, 334-339. 
http://dx.doi.org/10.1097/00000542-200108000-00012

[68] Campbell, N.J. (2010) Effective Management of the Post Dural Puncture Headache. Anaesthesia Tutorial of the Week, UK.

[69] Colonna-Romano, P. and Shapiro, B.E. (1989) Unintentional Dural Puncture and Prophylactic Epidural Blood Patch in Obstetrics. Anesthesia \& Analgesia, 69, 522-523. http://dx.doi.org/10.1213/00000539-198910000-00018

[70] Ackerman, W.E. and Colclough, G.W. (1987) Prophylactic Epidural Blood Patch: The Controversy Continues. Anesthesia \& Analgesia, 66, 913. http://dx.doi.org/10.1213/00000539-198709000-00022

[71] Scavone, B.M., Wong, C.A., Sullivan, J.T., Yaghmour, E., Sherwani, S.S. and McCarthy, R.J. (2004) Efficacy of a Prophylactic Epidural Blood Patch in Preventing Post Dural Headache in Parturients after Inadvertent Dural Puncture. Anesthesiology, 101, 1422-1427. http://dx.doi.org/10.1097/00000542-200412000-00024

[72] Stein, M.H., Cohen, S., Mohiuddin, M.A., Dombrovskiy, V. and Lowenwirt, I. (2014) Prophylactic vs. Therapeutic Blood Patch for Obstetric Patients with Accidental Dural Puncture: A Randomized Controlled Trial. Anaesthesia, 69, 320-326. http://dx.doi.org/10.1111/anae.12562

[73] Chen, A. and Hillen, M. (2015) Intraventricular Blood and Pneumocephalus after Epidural Blood Patch. Neurology, 84, 317.

[74] Rice, G.G. and Dabbs, C.H. (1950) The Use of Peridural and Subarachnoid Injections of Saline Solution in the Treatment of Severe Post Spinal Headache. Anesthesiology, 11, 17-23. http://dx.doi.org/10.1097/00000542-195001000-00003

[75] Abdullah, S., Abdullah, W. and Eckhardt, R. (2011) Caudal Normal Saline Injections for the Treatment of Post Dural Puncture Headache. Pain Physician, 14, 271-279.

[76] Bart, A.J. and Wheeler, A.S. (1978) Comparison of Epidural Saline Placement and Epidural Blood Placement in the Treatment of Post-Lumbar-Puncture Headache. Anesthesiology, 48, 221-213. http://dx.doi.org/10.1097/00000542-197803000-00012

[77] Eldor, J., Guedj, P. and Cotev, S. (1990) Epidural Morphine Injections for the Treatment of Post Spinal Headache. Canadian Journal of Anesthesia, 37, 710-711. http://dx.doi.org/10.1007/BF03006510

[78] Al-Metwalli, R.R. (2008) Epidural Morphine Injections for Prevention of Post Dural Puncture Headache. Anaesthesia, 63, 847-850. http://dx.doi.org/10.1111/j.1365-2044.2008.05494.x

[79] Gill, F., Grcia-Aguado, R., Barcia, J.A., Guijarro, E., Hostalet, F., Tommasi-Rosso, M. and Grau, F. (1998) The Effect of Fibrin Glue Patch in an in Vitro Model of Post Dural Puncture Leakage. Anesthesia \& Analgesia, 87, 1125-1128.

[80] Saxena, S., Jain, P. and Shukla, J. (2003) Preparation of Two Component Fibrin Glue and Its Clinical Evaluation in Skin Grafts and Flaps. Indian Journal of Plastic Surgery, 36, 14-17.

[81] Ben, J., Crul, P., Gerritse, B.M., van Dongen, R.T.M. and Schoonderwaldt, H.C. (1999) Epidural Fibrin Glue Injection Stops Persistent Post Dural Puncture Headache. Anesthesi- 
ology, 91, 576-577. http://dx.doi.org/10.1097/00000542-199908000-00039

[82] Heesen, M., Klohr, S., Rossaint, R., Walters, M., Straube, S. and van de Velde, M. (2013) Insertion of an Intrathecal Catheter Following Accidental Dural Puncture: A Meta-Analysis. International Journal of Obstetric Anesthesia, 22, 26-30.

http://dx.doi.org/10.1016/j.ijoa.2012.10.004

[83] Camporesi, E.M. and Bosco, G. (2014) Mechanism of Action of Hyperbaric Oxygen Therapy. Undersea and Hyperbaric Medicine, 41, 247-252.

[84] Shih, C.-C., Tsai, S.H., Liao, W.I., Wang, J.C. and Hsu, C.W. (2015) Successful Treatment of Epidural Anesthesia-Induced Severe Pneumocephalus by Hyperbaric Oxygen Therapy. American Journal of Emergency Medicine, 33, 1116.e1-1116.e3.

http://dx.doi.org/10.1016/j.ajem.2015.01.044

[85] Paiv,a W.S., Andrade, A.F., Figueiredo, E.G., Amorim, R.L., Prudente, M. and Teixeira, M.J. (2014) Effects of Hyperbaric Oxygenation Therapy on Symptomatic Pneumocephalus. Therapeutics and Clinical Risk Management, 10, 769-773. http://dx.doi.org/10.2147/TCRM.S45220

[86] Keener, E.B. (1959) An Experimental Study of Reactions of the Dura Mater to Wounding and Loss of Substance. Journal of Neurosurgery, 16, 424-447.

http://dx.doi.org/10.3171/jns.1959.16.4.0424

\section{Submit or recommend next manuscript to SCIRP and we will provide best service} for you:

Accepting pre-submission inquiries through Email, Facebook, LinkedIn, Twitter, etc. A wide selection of journals (inclusive of 9 subjects, more than 200 journals)

Providing 24-hour high-quality service

User-friendly online submission system

Fair and swift peer-review system

Efficient typesetting and proofreading procedure

Display of the result of downloads and visits, as well as the number of cited articles

Maximum dissemination of your research work

Submit your manuscript at: http://papersubmission.scirp.org/

Or contact ojanes@scirp.org 